\title{
Characterization and Usage of Tule (Typha domingensis Pers) to Obtain Cellulose Pulp in a Biorefinery Framework
}

\author{
Javier M. Loaiza, ${ }^{\mathrm{a}, *}$ Minerva A. Zamudio, ${ }^{\mathrm{b}}$ Susana, Lozano, ${ }^{\mathrm{a}}$ Ascension Alfaro, ${ }^{\mathrm{c}}$
} Maria T. Garcia, ${ }^{a}$ Juan C. García, ${ }^{a}$ and Francisco Lopez ${ }^{a}$

\begin{abstract}
It was proposed that pre-hydrolysing tule (Typha domingensis Pers) would make it possible to produce handsheets with strength-related properties similar to those of conventional commercial paper, in addition to valorizable hemicelluloses. The hypothesis was tested with a biorefining scheme involving autohydrolysis. Conditions were optimized to maximize the extraction of hemicelluloses while preserving glucan integrity. The autohydrolysis at a liquid to solid ratio of 13 at $141^{\circ} \mathrm{C}$ for $45 \mathrm{~min}$ (optimized conditions) provided a commercially useful liquor containing primarily tule hemicelluloses. The autohydrolysis of tule before alkaline extraction made it possible to obtain a valuable liquid phase comprising between $23.3 \%$ and $71.6 \%$ of all hemicelluloses in the raw material. The gross heating value for the hydrolyzed tule was increased $(1.6 \%$ to $7.9 \%)$ with respect the raw material. The solid phase was subjected to soda-anthraquinone pulping. The yield, ethanol extractives, kappa number, viscosity, glucan, xylan, Klason lignin, soluble lignins, as well as the tensile index were evaluated. Tule was found to be amenable to industrial processing for the production of quality cellulose derivatives. Autohydrolysis provided valorizable liquor in addition to solid that yielded soda-anthraquinone pulp having properties similar to those obtained in its absence, but using milder operating conditions.
\end{abstract}

Keywords: Autohydrolysis; Biorefinery; Hemicelluloses; Pulp; Soda-AQ; Tule

Contact information: a: Research Center in Technology of Products and Chemical Processes (PRO2TEC), Department Chemical Engineering, University of Huelva, Huelva 21071 Spain; $b$ : Technological Institute of Ciudad Madero, Ciudad Madero 89460 Mexico; c: Forestry Science Department, University of Huelva, Huelva 21071 Spain; *Corresponding author: javiermauricio.loiza@diq.uhu.es

\section{INTRODUCTION}

The sustainable development of renewable industrial products of high added value is becoming increasingly essential to reverse the growing de-industrialization and delocalization occurring in many countries. To this end, the forest sector and, more specifically, the pulp and paper industry, are searching for alternative, non-wood plant fibres (Mongkhonsiri et al. 2018; Daya and Nourelfath 2019; Pio et al. 2020). In addition, these industries are fostering research into the integral fractionation and biorefining of lignocellulosic materials to obtain a number of products in addition to pulp and energy by using processing schemes similar to those found in oil refining processes (Cherubini 2010; Zhu and Zhuang 2012; Nanda et al. 2015; Cebreiros et al. 2017). In theory, existing schemes for cellulose pulp production could be used at industrial plants for the conversion of lignocellulosic biomass into biorefinable fractions in order to increase profits in the 
forest and paper industries (Clark et al. 2009; Vila et al. 2011; Pätäri et al. 2016; Rogers et al. 2018).

The world output of paper varies to an extent dependent on the particular type of product. Overall, the production of graphic art paper is on the decline as a result of the increasing usage of digital media in developed countries; in contrast, the production of packaging paper is increasing as a result of the ever-stringent restrictions on plastics (Bajpai 2016). Thus, according to FAO statistics (2018), 57\% of all paper and board produced in 2018 (235 million tonnes) was used to manufacture packaging materials. In any case, cellulose pulp production continues to steadily rise and has increased from 400 million tons to 415 million tons, i.e., by 3.85\%, in 2018 (FAO 2018). Since 97\% of all paper is currently obtained from wood raw materials, there is good reason to explore new sources of lignocellulosic biomass including agricultural and forest residues (Chen et al. 2014; Moriana et al. 2015; Wikberg et al. 2017; Cypriano et al. 2018; FAO 2018; Bian et al. 2019).

The growing interest in increasing the sustainability and decreasing the environmental impact of cellulose pulp and paper production has fostered a search for alternative, non-wood sources of fibre (Khiari et al. 2010; López et al. 2012; Krishnan et al. 2015; Ang et al. 2020). However, only 3\% of the inputs for paper production comes from such sources currently (FAO 2018). The alternatives have the advantage of much shorter crop cycles, which is the case with the plant species used as raw material in this study, i.e., tule.

Tule (Typha domingensis Pers) is an aquatic plant native to America that occasionally acts as an invader and forms highly dense colonies known as totorales. Tule is a highly competitive species with a high reproductive rate. A hectare of tule plants can provide an approximate 55 tonnes of green matter up to three times a year (Medina 1959; Morales-Cepeda et al. 2015). This is a rather high biomass production rate relative to conventional forest crops. In addition, the fact that tule roots tend to accumulate heavy metals, nitrates, and phosphates allows metals in water masses to be eliminated by removing the plants (Vera et al. 2010).

The conventional scheme for cellulose pulp production based on alkaline delignification can be upgraded by inserting a previous autohydrolysis step to selectively extract hemicelluloses into the resulting liquor. The liquor, which is rich in hemicellulose polymers (primarily xylo-oligosaccharides and xylose), provides a promising source of products with high added value for usage in the pharmaceutical, chemical, and food industries. In addition, the fermentation medium obtained can be used for fuels and chemicals, e.g., ethanol, furfural, and xylitol (Rivas et al. 2002; García et al. 2011; GarcíaDomínguez et al. 2013; Moniz et al. 2014). Destroying lignocellulosic material by hydrolysis or autohydrolysis has an additional environmental advantage: it facilitates subsequent delignification and avoids the need to use sulphur compounds for this purpose. Treating the hydrolysed raw material with an alkaline reagent, e.g., a soda-anthraquinone or ethanol-soda-anthraquinone mixture, allows cellulose pulp with a low residual lignin content, a high yield and brightness, and good strength-related properties to be obtained (Caparrós et al. 2008; Alfaro et al. 2009, 2010; García et al. 2017; Loaiza et al. 2019).

The effects of a hydrothermal pretreatment on the outcome of the subsequent pulping process has been examined in a wide variety of raw materials. Thus, autohydrolysis has been used prior for the kraft, soda, and ethanol-water pulping of eucalyptus (Loaiza et al. 2016), Leucaena leucocephala K360 (Feria et al. 2011), Arundo donax (Caparros et al. 2007), tagasaste (Chamaecytisus proliferus) (Alfaro et al. 2010), Paulownia fortunei L 
(Caparrós et al. 2008), and Leucaena diversifolia (Feria et al. 2012). The fact that the properties of the resulting pulp were invariably similar to those obtained without a hydrolysis treatment led the authors to explore a new raw material, i.e., tule (Typha domingensis Pers). In this work, tule was subjected to integral fractionation via autohydrolysis and back-delignification, the autohydrolysis liquor was assessed as a source of monosaccharides and hemicellulose derivatives, and the remaining solid phase was assessed as a raw material for energy, pulp, and paper production.

\section{EXPERIMENTAL}

\section{Materials}

Characterization and storage of the raw material

Tule plants were obtained from an industrial wastewater receiving body located in the El Conejo lagoon (Altmirade, Tamaulipas region, Mexico). In the present case, it was decided that the plant stems were cut above the water mirror surface. The roots were not of interest, as they usually contain large amounts of metals and nutrients. The raw material was prepared for treatment according to TAPPI standard T257 cm-85 (1999). The stems were chopped to pieces that were approximately $2.5 \mathrm{~cm}$ long and stored in air-tight pouches to protect them from ambient moisture (César et al. 2015).

The tule was characterized chemically according to TAPPI standard T264 cm-07 (2007) for its moisture content, TAPPI standard 211 om-02 (2002) for its ash content, and TAPPI standard T204 cm-07 (2007) with Soxhlet extraction (95\% ethanol for $5 \mathrm{~h}$ ) for its ethanol extractives. After characterization, the raw material was ground to a particle size of less than $0.5 \mathrm{~mm}$ and subjected to quantitative acid hydrolysis with $72 \% \mathrm{H}_{2} \mathrm{SO}_{4}$. The resulting hydrolysates were chemically analysed according to TAPPI standard T249 cm09 (2009). The monomeric sugar content (arabinose, xylose, and glucose) as well as the acetic acid content in the hydrolysis liquor were determined via HPLC (high performance liquid chromatography), using an Aminex HPX-87H ion exchange column at a temperature of $30{ }^{\circ} \mathrm{C}$ as the stationary phase and $0.05 \mathrm{M}$ of $\mathrm{H}_{2} \mathrm{SO}_{4}$ at a flow rate of $6 \mathrm{~mL} / \mathrm{min}^{-1}$ as the mobile phase. The monosaccharide contents were expressed as xylan, araban, or glucan. The Klason and soluble lignin contents were determined according to TAPPI standard T222 om-11 (2011).

\section{Methods}

Autohydrolysis

The tule samples and the reaction liquid (water) were mixed in the established proportions and reacted in a $10 \mathrm{~L}$ stainless-steel reactor from MK-Systems, Inc. (North Adams, MA) with recycling. The operational conditions for autohydrolysis were as follows: a temperature of $141{ }^{\circ} \mathrm{C}$ to $165{ }^{\circ} \mathrm{C}$ for $15 \mathrm{~min}$ to $45 \mathrm{~min}$, a warm-up time of 43 $\mathrm{min}$, and a liquid to solid ratio of $13 \mathrm{~kg}$ of water to $1 \mathrm{~kg}$ of raw material. Once the reactor was closed, it was heated and actuated to ensure thorough mixing and uniform swelling of the tule chips. After autohydrolysis, the reactor was cooled down to $25^{\circ} \mathrm{C}$.

\section{Determination of the gross heating values}

The gross heating values (constant volume) were determined according to CEN/TS standard 14918 (2005) and UNE standard 16001 EX (2005), using a Parr 6300 automatic isoperibol (bomb) calorimeter and $1.0 \mathrm{~g}$ of pellets in each run. For measurements, a cotton 
thread was attached to a platinum ignition wire and placed in contact with the pellets. The calorimeter bomb (a stainless steel box) was filled with oxygen at a temperature of $25^{\circ} \mathrm{C}$ and with $1.0 \mathrm{~cm}^{3}$ of water, and then placed in the isothermal jacket of the calorimeter with an air gap of $10 \mathrm{~mm}$ between the surfaces of the jacket and bomb walls. The amount of electrical energy needed for ignition was determined from the potential difference across a 1256 or $2900 \mu \mathrm{F}$ capacitor discharged from approximately $40 \mathrm{~V}$ through a platinum wire. The calorimeter jacket was kept at a constant temperature by circulating water at a temperature of $27^{\circ} \mathrm{C}$.

\section{Pulping}

The solid phase from the autohydrolysis process was pulped in the same reactor as the hydrothermal treatment. The reactor was heated and actuated to ensure thorough mixing and uniform swelling of the tule chips. The pretreated raw material was pulped at three different alkali concentrations (14 dry wt $\%, 17$ dry wt $\%$, or 20 dry wt $\%$ of $\mathrm{NaOH}$ ), temperatures $\left(153{ }^{\circ} \mathrm{C}, 163{ }^{\circ} \mathrm{C}\right.$, or $171{ }^{\circ} \mathrm{C}$ ) and cooking times (60 min, $90 \mathrm{~min}$, or $120 \mathrm{~min}$ ), in addition to a fixed liquid to solid ratio (13 to 1$)$ and anthraquinone concentration $(0.1$ dry wt\%). After the pulping time had elapsed, the reactor was cooled down to $25^{\circ} \mathrm{C}$. Following the cooking procedure, the liquor of each pulp sample was filtered off and disintegrated at $2000 \mathrm{rpm}$ for $10 \mathrm{~min}$. The pulping yield, kappa index, and intrinsic viscosity were determined according to TAPPI standard T230 om-99 (1999), TAPPI standard T236 cm-85 (1996), and TAPPI standard T257 cm-85 (1999), respectively. The paper sheets were prepared according to TAPPI standard T205 sp-02 (2014) using a ENJOF-39.71 sheet machine and assessed for grammage using TAPPI standard T220 sp-01 (2001) and for tensile index using TAPPI standard T494 om-01 (2001).

\section{Experimental design for the autohydrolysis and pulping processes using multiple regression models}

The autohydrolysis and pulping processes were modelled and optimized using polynomials comprised of linear and quadratic terms describing the process variables, and their mutual interactions; therefore, the equations established were fit using multiple regressions. A $2^{n}$ central composite factor design was used to reduce the number of tests needed while ensuring the absence of significant covariances between the dependent variables. This allowed the dependent variables, i.e., the Klason lignin, yield, soluble lignin, glucan, araban, xylan, acetyl groups, and higher heating value, to be related to the independent variables, i.e., the temperature, $\mathrm{NaOH}$ concentration, and treatment time.

Modelling required previously normalizing the ranges spanned by the independent variables by applying an equation and identifying the statistically significant influences on the coefficients. This equation was defined as Eq. 1,

$$
X_{n}=\frac{X-\bar{X}}{\left(X_{\max }-X_{\min }\right) \div 2}
$$

where $X$ is the absolute value of the independent variable concerned, $\bar{X}$ is the average value, and $X_{\max }$ and $X_{\min }$ are the maximum and minimum values, respectively. Thus, no term with a $p$-value greater than 0.05 as per a Student's $t$-test or spanning a confidence interval less than $95 \%$ wide was included.

The number of tests was calculated according to Eq. 2,

$$
N=2^{n}+2 \cdot n+n \mathrm{C}
$$


where $2^{n}$ is the number of points constituting the factor design, $2 \cdot n$ is the number of axial points, and $n_{\mathrm{C}}$ is the number of central points.

$N$ was 10 for the autohydrolysis process and 16 for the pulping process. The experimental results were fit to the following second-order polynomial equation shown in Eq. 3,

$$
Y=a_{0}+\sum_{i-1}^{n} b_{i} X_{n i}+\sum_{i-1}^{n} c_{i} X_{n i}^{2}+\sum_{i-1, j-1}^{n} d_{i} X_{n i} X_{n j}(i<j)
$$

where $X$ denotes the independent variables and $Y$ denotes the dependent variables and the coefficients $a_{o}, b_{i}, c_{i}$, and $d_{i j}$ are constant characteristics in each model estimated with the experimental data.

The results were assessed with the Statistica software (Version 10.0, StatSoft, Inc., Tulsa, OK). Universal fitting statistics, i.e., $\mathrm{R}^{2}$ and Snedecor's F-value, were also used. An $\mathrm{R}^{2}$ greater than 0.85 or an $\mathrm{F}$ value greater than 5 were taken as acceptable.

To establish a basis for comparison, samples of the untreated tule (without autohydrolysis) were also subjected to soda-anthraquinone delignification under the same pulping conditions as the test that providing the best pulp properties via autohydrolysis, i.e., an alkali concentration of $20 \%$, a temperature of $171^{\circ} \mathrm{C}$, and a cooking time of 120 $\min$.

\section{RESULTS AND DISCUSSION}

\section{Chemical Characterization of Tule}

The potential of tule as a renewable source for the sustainable production of paper and chemicals (specifically, hemicellulose derivatives) was assessed by comparison with a reference material (Eucalyptus globulus wood) and was subjected to the treatment proposed by Lopez et al. (2015), which involved autohydrolysis and delignification.

Table 1 summarizes the chemical properties of the raw material as determined in this study. As can be seen, the material primarily consisted of cellulose (quantified as $\alpha-$ cellulose), as well as lesser amounts of Klason lignins (determined after quantitative acid hydrolysis), hemicelluloses $(23.9 \%)$, which was calculated as the combination of xylan $(18.8 \%)$, araban $(2.0 \%)$, and acetyl groups $(3.1 \%)$. This composition is considerably different from the composition of other raw materials used in biorefinery schemes (Pan and Sano 2005; Alfaro et al. 2009, 2010; Caparrós et al. 2007, 2008). Wheat straw and E. globulus contained $38.3 \%$ and $20.0 \%$ more glucan ( $\alpha$-cellulose), respectively, than tule. César et al. (2015) reported a $15.9 \%$ higher $\alpha$-cellulose content in tule than the content found in this study; however, their hemicellulose content, calculated as the difference between the holocellulose and glucan content, was unusually low (11.5\%). Nevertheless, Khider et al. (2012) report only a 4.5\% higher $\alpha$-cellulose content in tule (from Sudan) than the content found in this study and their hemicelluloses content (as pentosans) is unusually high $(32.8 \%)$, although analytical methodologies were not the same. The hemicellulose content found in this study was $23.9 \%$ lower than the content in sunflower stalks and tagasaste, but was similar to the content in L. diversifolia, wheat straw, and A. donax $(27.8 \%, 20.8 \%$, and $29.7 \%$, respectively). A low hemicellulose content would make the prior extraction of this fraction from the raw material inadvisable with consideration to its valorization (Saha 2003; Fišerová et al. 2012). The ethanol content in the extractives of tule was also different from the content in the other raw materials. However, it was identical with the contents reported by César et al. (2015) and similar to those for A. donax. This 
difference is typical of grassy materials, e.g., tule or A. donax. The Klason lignin content of tule was similar to the content of the woody species shown in Table 1. Although the ease of delignification of a raw material depends on its lignin content as well as the structural properties of the lignin fraction, tule should be easier to delignify than other woody species (Yedro et al. 2015; Yoo et al. 2020).

This work was undertaken to test the hypothesis that tule is amenable to the valorization of its hemicellulosic fraction via autohydrolysis and that the resulting solid phase will require milder operating conditions than other woody species.

Table 1. Chemical Composition of Tule and Other Raw Materials

\begin{tabular}{|c|c|c|c|c|c|}
\hline Component & $\begin{array}{c}\text { Ethanol } \\
\text { Extractives } \\
(\%)\end{array}$ & $\begin{array}{c}\text { Holocellulose } \\
(\%)\end{array}$ & $\begin{array}{c}\text { a-Cellulose } \\
(\%)\end{array}$ & $\begin{array}{c}\text { Klason } \\
\text { Lignin } \\
(\%)\end{array}$ & $\begin{array}{c}\text { HHV } \\
(\mathrm{kJ} / \mathrm{kg})^{\mathrm{i}}\end{array}$ \\
\hline $\begin{array}{c}\text { Tule } \\
\text { (Present study) }\end{array}$ & 11.1 & 58.1 & 34.2 & 24.3 & 17318 \\
\hline $\begin{array}{c}\text { Tule (César et al. } \\
\text { 2015/ Khider et al. } \\
\text { 2012) }\end{array}$ & $11.5 / 13.6$ & $61.6 / 67.6$ & $50.1 / 38.7$ & $21.2 / 17.5$ & - \\
\hline $\begin{array}{c}\text { Sunflower stalks } \\
\text { (Caparrós et al. 2008) }\end{array}$ & - & 74.2 & 33.8 & 19.9 & 17259 \\
\hline $\begin{array}{c}\text { Leucaena diversifolia } \\
\text { (Alfaro et al. 2009) }\end{array}$ & 1.7 & 65.8 & 38.0 & 24.8 & 18954 \\
\hline $\begin{array}{c}\text { Tagasaste } \\
\text { (Chamaecytisus } \\
\text { proliferus) (Alfaro et al. } \\
\text { 2010) }\end{array}$ & 2.3 & 80.3 & 38.9 & 19.8 & 19564 \\
\hline $\begin{array}{c}\text { Wheat straw (Pan and } \\
\text { Sano 2005) }\end{array}$ & 5.3 & 76.2 & 55.4 & - & - \\
\hline $\begin{array}{c}\text { Arundo donax } \\
\text { (Caparros et al. 2007) }\end{array}$ & 9.1 & 64.5 & 34.8 & 23.0 & 19163 \\
\hline $\begin{array}{c}\text { Eucalyptus globulus } \\
\text { (Loaiza et al. 2016) }\end{array}$ & 2.7 & 64.1 & 42.8 & 21.2 & - \\
\hline Note: i denotes a higher heating value on a dry basis & & & \\
\hline
\end{tabular}

Before the chemical composition of the post-hydrolysis solid and its amenability to pulping were assessed, the authors considered the feasibility of using the solid or the untreated raw material in order to obtain energy. The energy potential of the raw material was assessed by comparing its heating value with the heating value of various other materials. The higher heating value (HHV) of biomass typically ranges from $17598 \mathrm{~kJ} / \mathrm{kg}$ to $18681 \mathrm{~kJ} / \mathrm{kg}$, whereas the HHV of tule has been estimated as $17318 \mathrm{~kJ} / \mathrm{kg}$, which is similar to the value of sunflower and only $8.6 \%$ lower than L. diversifolia (as shown in Table 1). Therefore, the energy content of tule is amenable to exploitation by combustion with the added advantages of a low environmental impact, a high productivity, and the absence of competition with food-related uses, e.g., starches and cereals. Consequently, tule can be a suitable lignocellulosic biomass for the industrial production of hemicellulosic derivatives, pulp, and paper. For example, the autohydrolysis liquor could be used to obtain furfural, which requires a minimum $\mathrm{C}_{5}$ sugar content of $15 \%$ to $20 \%$ in the raw material (Mussatto and Mancilha 2007; Patel and Goyal 2011; Cara et al. 2012). 


\section{Hydrothermal Treatment}

Table 2 shows the values of the independent variables used in accordance with the experimental design and the composition of the resulting solid fractions from autohydrolysis as percentages of the hydrolyzed material. Glucan was the individual polysaccharide that was least affected by autohydrolysis; its content was decreased by $36.7 \%$ to $43.6 \%$, i.e., $76.8 \%$ and $89.1 \%$ of the initial content was preserved. This result is important because a biorefinery process, including paper production, requires the presence of a large amount of sugars in solution but low amounts of cellulose (glucan) degradation in the raw material in order to provide pulp with acceptable properties (Alfaro et al. 2010).

Table 2. Normalized Values of the Process Variables (Independent Variables) After the Autohydrolysis of Tule and the Composition of the Resulting Solid

\begin{tabular}{|c|c|c|c|c|c|c|c|c|c|c|}
\hline$X_{T}$ & $X_{t}$ & $\begin{array}{c}\text { Yield } \\
(\%)\end{array}$ & $\begin{array}{c}\text { Glucan } \\
(\%)\end{array}$ & $\begin{array}{c}\text { Xylan } \\
(\%)\end{array}$ & $\begin{array}{c}\text { Araban } \\
(\%)\end{array}$ & $\begin{array}{c}\text { Acetyl } \\
\text { Groups } \\
(\%)\end{array}$ & $\begin{array}{c}\text { Klason } \\
\text { lignin } \\
(\%)\end{array}$ & $\begin{array}{c}\text { Soluble } \\
\text { lignin } \\
(\%)\end{array}$ & $\begin{array}{c}\mathrm{HHV} \\
(\mathrm{kJ} / \mathrm{kg})^{\mathrm{a}}\end{array}$ & $\begin{array}{c}\mathrm{THE} \\
(\%)\end{array}$ \\
\hline-1 & -1 & 77.8 & 37.9 & 19.3 & 1.3 & 3.0 & 23.5 & 1.7 & 17597 & 23.3 \\
\hline-1 & 0 & 78.8 & 36.7 & 18.2 & 1.1 & 2.2 & 21.4 & 1.7 & 17714 & 28.9 \\
\hline-1 & 1 & 80.4 & 38.0 & 18.5 & 1.2 & 2.9 & 27.1 & 1.9 & 18292 & 24.0 \\
\hline 0 & -1 & 74.3 & 38.7 & 18.1 & 1.0 & 2.3 & 28.8 & 1.8 & 17731 & 32.3 \\
\hline 0 & 0 & 72.2 & 39.7 & 17.5 & 0.7 & 1.6 & 23.7 & 1.6 & 17840 & 39.9 \\
\hline 0 & 0 & 72.3 & 39.6 & 17.5 & 0.7 & 1.6 & 24.6 & 1.6 & 17831 & 39.9 \\
\hline 0 & 1 & 70.6 & 40.2 & 15.5 & 0.5 & 2.1 & 28.1 & 1.5 & 18413 & 48.4 \\
\hline 1 & -1 & 69.6 & 40.7 & 16.1 & 0.9 & 1.8 & 29.4 & 1.5 & 18020 & 45.0 \\
\hline 1 & 0 & 65.5 & 42.6 & 11.8 & 0.5 & 1.2 & 21.9 & 1.3 & 18187 & 62.6 \\
\hline 1 & 1 & 60.3 & 43.6 & 9.2 & 0.4 & 1.7 & 25.0 & 1.6 & 18681 & 71.6 \\
\hline
\end{tabular}

Note: ${ }^{a}$ denotes a higher heating value on a dry basis; temperature is $X_{T}$, time is $X_{t}$, and THE is total hemicellulose extracted

Using a high temperature $\left(165^{\circ} \mathrm{C}\right)$ during the hydrothermal treatment reduced the glucan content of the resulting solids by $40.7 \%$ to $43.6 \%$, so $76.8 \%$ to $81.4 \%$ of the initial content was retained. However, using low and medium temperatures had the opposite effect. At a temperature of 141 and $153{ }^{\circ} \mathrm{C}$, the glucan content was reduced by $36.7 \%$ and $40.1 \%$, respectively, and $81.5 \%$ to $89.1 \%$ of all glucan was retained. The greatest increase in glucan $(89.1 \%)$ was obtained at $141{ }^{\circ} \mathrm{C}$ for $30 \mathrm{~min}$.

As a result of the autohydrolysis process, $19.6 \%$ of all biomass in the raw material was extracted into the liquor. The amount of soluble lignins were smaller in most cases ( $1.83 \%$ of the autohydrolysis solid phase). This result suggested substantial dissolution of this fraction due to the autohydrolysis treatment.

Thus, the Klason lignin content in the solid ranged from $21.9 \%$ to $29.8 \%$, i.e., $59.1 \%$ to $91.2 \%$ of the amount present in the raw material, therefore delignifying $8.8 \%$ to $40.9 \%$ of the Klason lignin content.

The xylose, araban, and acetyl groups contents exhibited substantial changes, i.e., $9.2 \%$ to $19.3 \%, 0.4 \%$ to $1.3 \%$, and $1.7 \%$ to $3.0 \%$, respectively, relative to the contents in the autohydrolysis solid. Therefore, the autohydrolysis $+\mathrm{NaOH}-\mathrm{AQ}$ treatment delignified $69.9 \%$ to $86.3 \%$ of the raw material.

The gross heating value for the hydrolyzed tule was $17598 \mathrm{~kJ} / \mathrm{kg}$ to $18681 \mathrm{~kJ} / \mathrm{kg}$, which is $280 \mathrm{~kJ} / \mathrm{kg}$ to $1364 \mathrm{~kJ} / \mathrm{kg}$ ( $1.6 \%$ to $7.9 \%)$ greater than that the gross heating value of the raw material. A high heating value for the autohydrolysis solid phase makes it useful for pulping, the production of chemicals, or burning. The increase in the heating value of 
tule via autohydrolysis exceeded the heating value of other materials previously autohydrolysed at a temperature range of 180 to $200{ }^{\circ} \mathrm{C}$. Thus, the increase was $0.06 \%$ to $2.1 \%$ for the reference material (E. globulus), $0.8 \%$ to $3.7 \%$ for L. diversifolia, $0 \%$ to $3.2 \%$ for $P$. fortunei, $0.01 \%$ to $1.1 \%$ for $A$. donax, and $0 \%$ to $1.7 \%$ for $C$. proliferus (López et al. 2011). Only sunflower stalks clearly exceeded tule in this respect, with an increase of $10.3 \%$ to $10.4 \%$. Additionally, the autohydrolysis of tule provided a liquor containing valuable chemicals.

The results for tule and the reference material E. globulus hydrolyzed at $180{ }^{\circ} \mathrm{C}$ for 30 min were similar; the autohydrolysis yield for eucalyptus was 84\% (Loaiza et al. 2016). The same as tule, the glucan fraction in eucalyptus was barely affected and the hemicelluloses were highly efficiently extracted, even slightly more efficient than tule. Thus, the autohydrolysis treatment recovered $65 \%$ to $82 \%$ of the hemicellulose content of E. globulus but only $23.3 \%$ to $71.6 \%$ from tule (Loaiza et al. 2016).

Based on the previous results, and on the reasoning of autohydrolysis, the optimum autohydrolysis conditions for tule were a temperature of $141{ }^{\circ} \mathrm{C}$ and a treatment time of 45 min. These conditions ensured a high cellulose (glucan) content in the solid phase and the presence of valorizable hemicellulosic derivatives in the liquor.

\section{Properties of the pulp and paper sheets}

As noted in the previous section, the autohydrolysis treatment increased the calorific value of the material via efficiently extracting hemicelluloses. However, the primary target of this work was the delignification of the resulting solid phase under a biorefinery scheme for pulp and paper production. This led the authors to use the autohydrolysis solid obtained under isothermal conditions at a temperature of $141{ }^{\circ} \mathrm{C}$ for 45 min as a pulping material.

Table 3. Normalized Values of the Process Variables (Independent Variables) and Properties of Pulp and Paper Sheets Obtained From the Autohydrolysis and Subsequent Delignification of Tule

\begin{tabular}{|c|c|c|c|c|c|c|c|c|c|c|c|}
\hline$X_{C}$ & $X_{t}$ & $X_{T}$ & $\begin{array}{c}\text { Yield } \\
(\%)\end{array}$ & $\begin{array}{c}\text { EE } \\
(\%)\end{array}$ & $\begin{array}{c}\text { Kappa } \\
\text { No. }\end{array}$ & $\begin{array}{c}\text { Klason } \\
\text { Lignin } \\
(\%)\end{array}$ & $\begin{array}{c}\text { Soluble } \\
\text { Lignin } \\
(\%)\end{array}$ & $\begin{array}{c}\text { Glucan } \\
(\%)\end{array}$ & $\begin{array}{c}\text { Xylan } \\
(\%)\end{array}$ & $\begin{array}{c}\text { Viscosity } \\
\left(\mathrm{cm}^{3} / \mathrm{g}\right)\end{array}$ & $\begin{array}{c}\text { Tensile } \\
\text { Index } \\
(\mathrm{N} \cdot \mathrm{m} / \mathrm{g})\end{array}$ \\
\hline 0 & 0 & 0 & 35.1 & 5.4 & 27.6 & 14.3 & 2.5 & 48.7 & 2.9 & 518 & 18.4 \\
\hline 0 & 0 & 0 & 34.7 & 5.5 & 29.0 & 15.1 & 2.2 & 48.7 & 2.9 & 517 & 18.3 \\
\hline 1 & 1 & 1 & 35.5 & 4.7 & 20.9 & 13.3 & 1.8 & 52.4 & 3.5 & 531 & 17.8 \\
\hline 1 & 1 & -1 & 34.1 & 9.6 & 26.5 & 12.5 & 1.9 & 51.6 & 4.3 & 524 & 18.7 \\
\hline 1 & -1 & 1 & 35.7 & 5.9 & 20.9 & 15.0 & 1.7 & 51.8 & 3.2 & 564 & 20.5 \\
\hline 1 & -1 & -1 & 39.1 & 12.0 & 29.9 & 12.3 & 1.5 & 47.6 & 4.8 & 517 & 22.4 \\
\hline-1 & 1 & 1 & 38.5 & 9.7 & 39.1 & 20.6 & 1.8 & 50.4 & 4.1 & 539 & 19.1 \\
\hline-1 & 1 & -1 & 41.3 & 10.6 & 34.6 & 21.9 & 1.4 & 48.7 & 5.1 & 499 & 20.7 \\
\hline-1 & -1 & 1 & 38.2 & 7.1 & 32.6 & 18.4 & 1.5 & 51.8 & 3.6 & 529 & 21.0 \\
\hline-1 & -1 & -1 & 44.5 & 8.8 & 33.5 & 21.4 & 1.4 & 48.9 & 5.1 & 481 & 22.3 \\
\hline 1 & 0 & 0 & 31.1 & 6.8 & 23.6 & 17.9 & 2.0 & 48.8 & 3.8 & 537 & 19.6 \\
\hline-1 & 0 & 0 & 37.2 & 7.3 & 33.0 & 24.5 & 1.8 & 47.9 & 4.2 & 520 & 20.2 \\
\hline 0 & 1 & 0 & 36.9 & 7.2 & 29.0 & 11.3 & 1.7 & 51.5 & 3.2 & 517 & 17.9 \\
\hline 0 & -1 & 0 & 39.6 & 6.3 & 30.3 & 11.6 & 1.7 & 49.8 & 3.1 & 513 & 19.7 \\
\hline 0 & 0 & 1 & 38.3 & 3.6 & 25.5 & 12.4 & 1.9 & 50.9 & 2.4 & 536 & 18.5 \\
\hline 0 & 0 & -1 & 37.4 & 7.0 & 31.3 & 13.3 & 1.8 & 48.3 & 4.2 & 496 & 19.7 \\
\hline
\end{tabular}

Note: $X_{C}$ is alkali concentration, $X_{T}$ is temperature, and $X_{t}$ is time; EE is ethanol extraction 
Table 3 shows the normalized values of the independent variables, the chemical composition of each pulp, and the tensile index of the resulting paper sheets obtained using the proposed experimental design. Each experimental value was the average of 12 results for the tensile index and 5 for the pulp properties. Deviations from the respective means were all less than $10 \%$.

The yield and viscosity of the soda-anthraquinone pulp obtained from autohydrolyzed tule were relatively low $\left(31.1 \%\right.$ to $44.5 \%$ and $481 \mathrm{~cm}^{3} / \mathrm{g}$ to $564 \mathrm{~cm}^{3} / \mathrm{g}$, respectively). This was a result of subjecting the raw material to two chemical processes in order to remove their lignocellulosic components. However, the prior extraction of hemicelluloses resulted in better kappa number values (20.9 to 39.1). The tensile index of the paper sheets was relatively good but low relative to commercial paper, which is typically obtained from mixed sources. In addition, refining the tule pulp could have led to substantially better properties (Duarte et al. 2011; Sarwar et al. 2012; Hamzeh et al. 2013).

The glucan content of the solid phase resulting from hydrolysis and delignification ranged from $47.6 \%$ to $52.2 \%$ of the initial amount present in the raw material; the former value was obtained via autohydrolysis with a 20 dry wt $\%$ alkali concentration at a temperature of $153{ }^{\circ} \mathrm{C}$ for $60 \mathrm{~min}$ and the latter was obtained with a 20 dry wt $\%$ concentration at temperature of $171^{\circ} \mathrm{C}$ for $120 \mathrm{~min}$. These glucan contents were similar to the content in eucalyptus wood $(48.7 \%)$ processed under similar conditions, i.e., 13 dry wt.\% alkali concentration at a temperature of $153{ }^{\circ} \mathrm{C}$ for $40 \mathrm{~min}$, but it was lower than the content for the same material subjected to stronger conditions $(80.4 \%)$, i.e., 17 dry wt\% alkali concentration at a temperature of $163{ }^{\circ} \mathrm{C}$ for $90 \mathrm{~min}$.

The Klason lignin content ranged from $11.3 \%$ with an alkali concentration of 17 dry wt $\%$ at a temperature of $163{ }^{\circ} \mathrm{C}$ for $120 \mathrm{~min}$ to $24.5 \%$ with an alkali concentration of 14 dry $\mathrm{wt} \% \mathrm{NaOH}$ at a temperature of $163{ }^{\circ} \mathrm{C}$ for $90 \mathrm{~min}$. Therefore, the autohydrolysis treatment delignified $69.9 \%$ to $86.3 \%$ of the raw material.

The xylan content never exceeded 6\%. Loaiza et al. (2016) previously found that autohydrolyzed, delignified E. globulus contained no xylan. The presence of hemicelluloses, even in small amounts, in the solid obtained after the two treatments of tule may have improved some strength-related properties, e.g., tensile index.

Loaiza et al. (2016) obtained a kappa number, viscosity, and tensile index of 29.0, $518 \mathrm{~cm}^{3} / \mathrm{g}$, and $18.3 \mathrm{~N} \cdot \mathrm{m} / \mathrm{g}$, respectively, for tule treated with a 17 dry $\mathrm{wt} \%$ alkali concentration at a temperature of $163{ }^{\circ} \mathrm{C}$ for $90 \mathrm{~min}$. Eucalyptus wood processed under identical conditions had a kappa number, viscosity, and tensile index of $32.9,769.2 \mathrm{~cm}^{3} / \mathrm{g}$, and $15.7 \mathrm{~N} \cdot \mathrm{m} / \mathrm{g}$, respectively. As shown by these results, the kappa index of the pulp and tensile index of the paper obtained from tule were both higher, but the viscosity of tule pulp was lower.

Based on the above results, tule can be subjected to autohydrolysis in order to destroy its lignin matrix with a view to its subsequent delignification for pulping and the obtainment of a valorizable liquor. The properties of the resulting pulp and paper sheets were similar to those previously obtained from E. globulus (Loaiza et al. 2016), L. diversifolia (Feria et al. 2012), and C. proliferus (Alfaro et al. 2010).

The optimal operating conditions for the autohydrolysis and delignification treatments were established as described below. The discussion that follows is based in part on the last paragraph of the hydrothermal treatment section in regards to the optimum autohydrolysis conditions. 
Table 4. Polynomial Models for the Dependent Variables of the Autohydrolysis and Pulping Processes

\begin{tabular}{|c|c|c|c|c|}
\hline & $\begin{array}{l}\text { Equation } \\
\text { Number }\end{array}$ & Equation & $\begin{array}{l}\text { Adjusted } \\
R^{2}\end{array}$ & $\begin{array}{l}\text { Snedecor's } \\
F\end{array}$ \\
\hline \multirow{8}{*}{ Autohydrolysis } & 1 & $Y I=72.18-6.93 X_{T}-1.73 X_{t}-2.97 X_{T} X_{t}$ & 0.99 & 1265,7 \\
\hline & 2 & $\mathrm{GL}=39.75+2.37 X_{T}+0.73 X_{t}+0.71 X_{T} X_{t}$ & 0.94 & 52.0 \\
\hline & 3 & $\begin{array}{c}\mathrm{X}=17.17-3.14 X_{T}-1.70 X_{t}-1.66 X_{T} X_{T}- \\
1.54 X_{T} X_{t}\end{array}$ & 0.96 & 59.5 \\
\hline & 4 & $\begin{array}{c}\mathrm{A}=0.69-0.30 X_{T}-0.20 X_{t}+0.13 X_{T} X_{T}+ \\
0.10 X_{t} X_{t}-0.10 X_{T} X_{t}\end{array}$ & 0.97 & 66.4 \\
\hline & 5 & $\begin{array}{c}\mathrm{AG}=1.60-0.55 X_{T}-0.06 X_{t}+0.11 X_{T} X_{T}+ \\
0.60 X_{t} X_{t}\end{array}$ & 0.98 & 206.2 \\
\hline & 6 & $\begin{array}{c}\mathrm{KL}=24.06-0.73 X_{T} X_{T}-2.34 X_{t} X_{t}+ \\
4.46 X_{T} X_{t}-1.98 X_{T} X_{t}\end{array}$ & 0.96 & 62.6 \\
\hline & 7 & $\mathrm{SL}=1.56-0.13 X_{T}+0.06 X_{t}-0.07 X_{t} X_{t}$ & 0.95 & 66.3 \\
\hline & 8 & $\begin{array}{c}\mathrm{THE}=41.59+17.17 X_{T}+7.23 X_{t}+ \\
6.47 X_{T} X_{t}\end{array}$ & 0.96 & 94.3 \\
\hline \multirow{8}{*}{$\begin{array}{l}\text { Pulping after } \\
\text { autohydrolysis }\end{array}$} & 9 & $\begin{array}{c}Y I=35.21-2.43 X_{C}-1.08 X_{t}-1.21 X_{T-} \\
1.19 X_{C} X_{C}+2.91 X_{t} X_{t}+1.47 X_{T} X_{T}+ \\
0.90 X_{C} X_{T}+1.03 X_{t} X_{T}\end{array}$ & 0.95 & 37.1 \\
\hline & 10 & $\begin{array}{l}\mathrm{EE}=5.35-0.45 X_{C}-1.70 X_{T}+1.75 X_{C} X_{C}+ \\
1.43 X_{t} X_{t}-1.0 X_{C} X_{t}-1.07 X_{C} X_{T}+0.24 X_{t} X_{T}\end{array}$ & 0.98 & 126.4 \\
\hline & 11 & $\begin{array}{c}\mathrm{KN}=29.36-5.10 X_{C}-1.49 X_{T}-1.36 X_{C} X_{t} \\
-2.28 X_{C} X_{T}+1.10 X_{t} X_{T}\end{array}$ & 0.95 & 62.4 \\
\hline & 12 & $\begin{array}{c}\mathrm{KL}=14.46-3.57 X_{C}+6.84 X_{C} X_{C} \\
2.90 X_{t} X_{t}-1.49 X_{T} X_{T}-0.52 X_{C} X_{t}+0.98 X_{C} X_{T}\end{array}$ & 0.98 & 125.7 \\
\hline & 13 & $\begin{array}{c}\mathrm{GL}=48.91+0.47 X_{C}+0.48 X_{t}+1.24 X_{T}- \\
0.69 X_{C} X_{C}+1.60 X_{t} X_{t}+0.58 X_{T} X_{T}+ \\
0.76 X_{C} X_{t}-0.60 X_{T} X_{t}\end{array}$ & 0.93 & 30.2 \\
\hline & 14 & $\begin{array}{c}X=3.0-0.25 X_{C}-0.61 X_{t}+1.15 X_{C} X_{C}+ \\
0.17 X_{t} X_{T}\end{array}$ & 0.96 & 107.9 \\
\hline & 15 & $\begin{array}{c}\mathrm{TI}=18.60-0.41 X_{C}-1.17 X_{t}-0.65 X_{T}+ \\
1.61 X_{C} X_{C}-0.36 X_{C} X_{t}\end{array}$ & 0.94 & 51.4 \\
\hline & 16 & $\begin{aligned} \mathrm{V}= & 516+10.7 X_{C}+18.2 X_{A}+8.0 X_{t}- \\
& 6.8 X_{C} X_{C}-4.2 X_{C} X_{T}-6.0 X_{t} X_{T}\end{aligned}$ & 0.94 & 37.4 \\
\hline \multicolumn{5}{|c|}{$\begin{array}{l}\text { Dependent variables: YI - yield (\%); GL - glucan (\%); X - xylan (\%); A - araban (\%); AG - acetyl } \\
\text { groups (\%); KL - Klason lignin (\%); } \mathrm{SL} \text { - soluble lignin (\%); EE - Ethanol extractives (\%); KN - } \\
\text { Kappa number; TI -Tensile index (N.m/g); V - viscosity (cm³/g); and THE - total hemicellulose } \\
\text { extracted (\%) } \\
\text { Independent variables: } X_{t} \text { (autohydrolysis or pulping time), } X_{T} \text { (autohydrolysis or pulping } \\
\text { temperature), and } X_{C} \text { alkali concentration (all expressed in coded units) } \\
\text { Variation coefficient between experimental and calculated values are less than } 10 \%\end{array}$} \\
\hline
\end{tabular}

As stated in the experimental design section, the influence the independent variables for autohydrolysis (temperature and time) and pulping (solid yield, glucose content, xylose content, arabinose content, acetyl group content, Klason lignins, soluble lignins, ethanol extractives, kappa number, viscosity, and tensile index) had on each dependent variable was used to construct the mathematical models shown in Table 4. Each value used to establish the equations was the average of three measurements. The differences between the experimental values and those predicted by the equations never exceeded $10 \%$. The fit was always quite good, with $\mathrm{R}^{2}$ greater than 0.90 in all cases.

In order to better envisage the influence of the operational variables on the outcome of the autohydrolysis and pulping processes, the authors constructed the hyperspaces of 
variation of the dependent variables in the form of response surfaces (as shown in Fig. 1 through Fig. 5). The most influential variable in each case was assigned either of the two extreme values $(+1$ or -1$)$. A combined plot of the results for the autohydrolysis and pulping processes revealed marked overlap between the spaces and allowed for the identification of the specific operating conditions affording production of cellulose pulp or paper with a given value of some property from the raw material.

\section{Graphical optimization of the autohydrolysis process}

Overall, the soda-AQ delignification of tule after autohydrolysis improved the paper properties (tensile index and kappa number). Extracting hemicelluloses has traditionally been assumed to have an adverse impact on the properties of paper sheets obtained from the post-hydrolysis solid; however, in this case, the fact that the solid retained a small portion of the hemicellulose fraction (most was extracted in the autohydrolysis liquor) resulted in improved strength-related properties and an increased kappa number in the produced paper sheets.

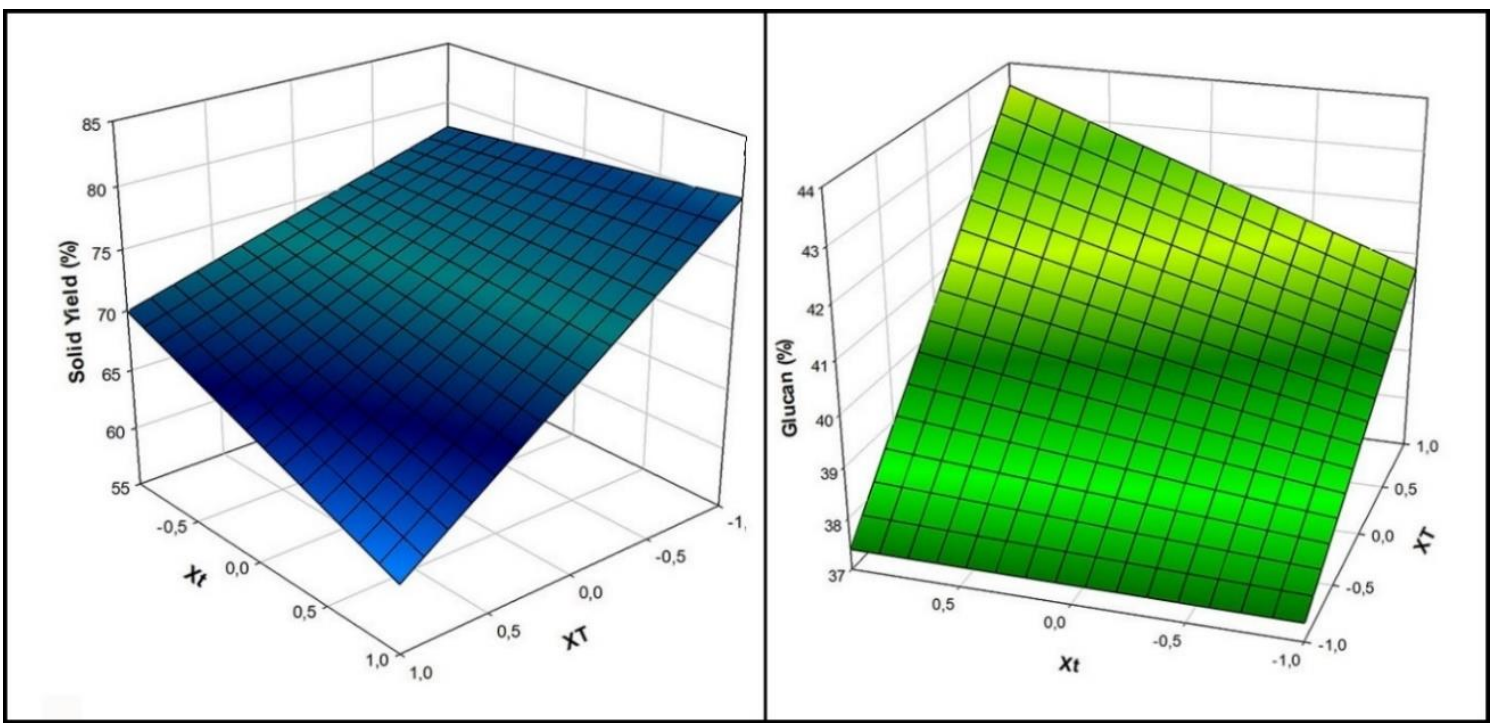

Fig. 1. Solid yield and glucan content of the solid as a function of the autohydrolysis temperature and treatment time

Figure 1 shows the percent yield and glucan content of the solid phase obtained from the autohydrolysis process at different temperatures and operation times relative to the raw material. As can be seen, the yield decreased but the glucan content increased as the temperature increased. Due to a combination of both effects, the highest glucan content in the solid (relative to the raw material) was obtained under the optimum autohydrolysis (hemicellulose extraction) conditions. However, these conditions (a temperature of $143{ }^{\circ} \mathrm{C}$ and $45 \mathrm{~min}$ ) resulted in the poor extraction of araban, xylan, and acetyl groups in the liquor, i.e., the highest proportion of xylan was in the solid phase (Fig. 2). However, these conditions allowed a substantial proportion of the hemicelluloses to be extracted from the raw material (25.2\%, based on equation 8 shown in Table 4), so they were chosen in order to avoid excessive degradation of the cellulose polymers. In addition, these conditions resulted in the maximal extraction of Klason lignins and soluble lignins in the autohydrolysis liquor (results not shown), which resulted in easier subsequent delignification (Fig. 2). 


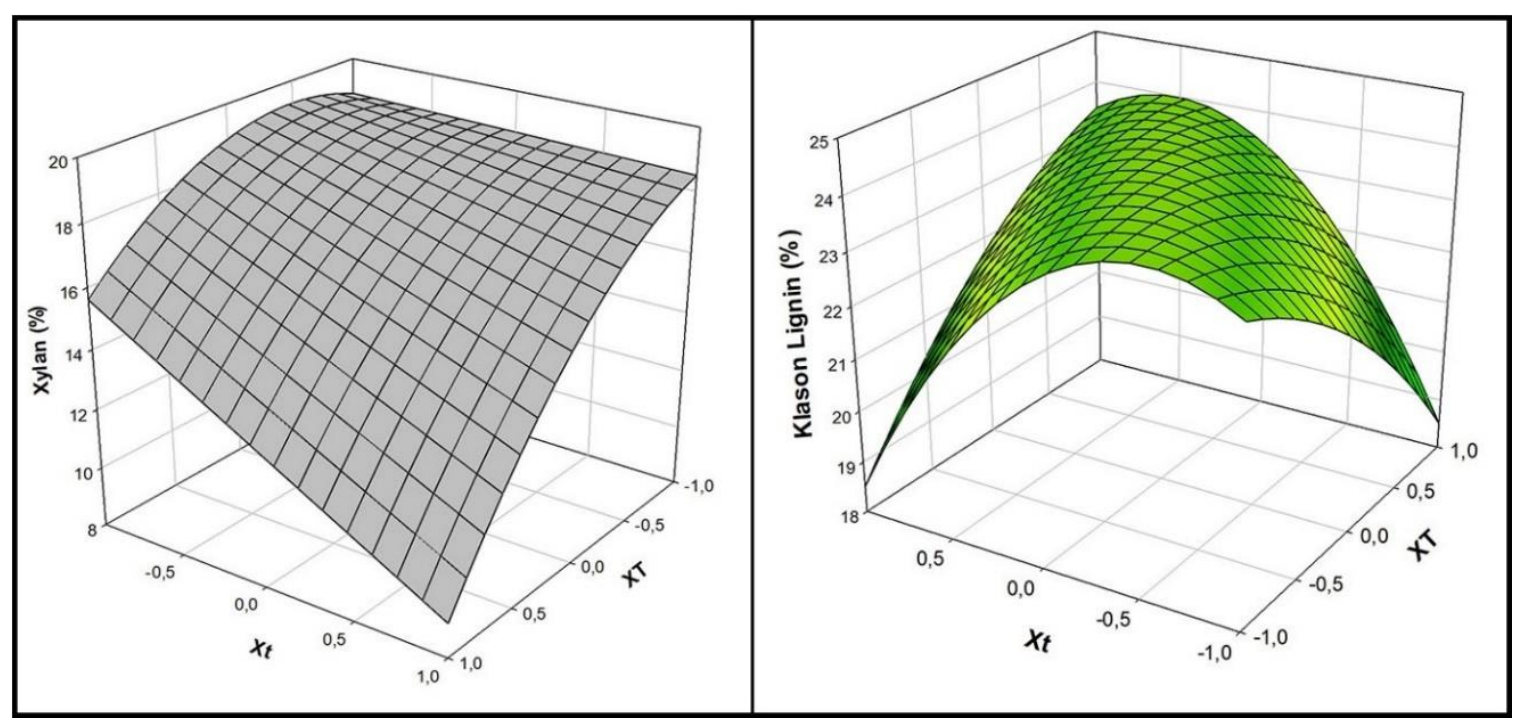

Fig. 2. Xylan and Klason lignin content in the solid as a function of the autohydrolysis temperature and time

Graphical optimization of the pulp and paper properties

Based on its response surface (not shown), the pulp yield was low as a result of the two-step fractionation of the raw material. Demonstrated by the kappa number (Fig. 3), there was substantial overlap at high active alkali concentrations (20\%). This property was much more sensitive to the soda concentration than the other independent variables.

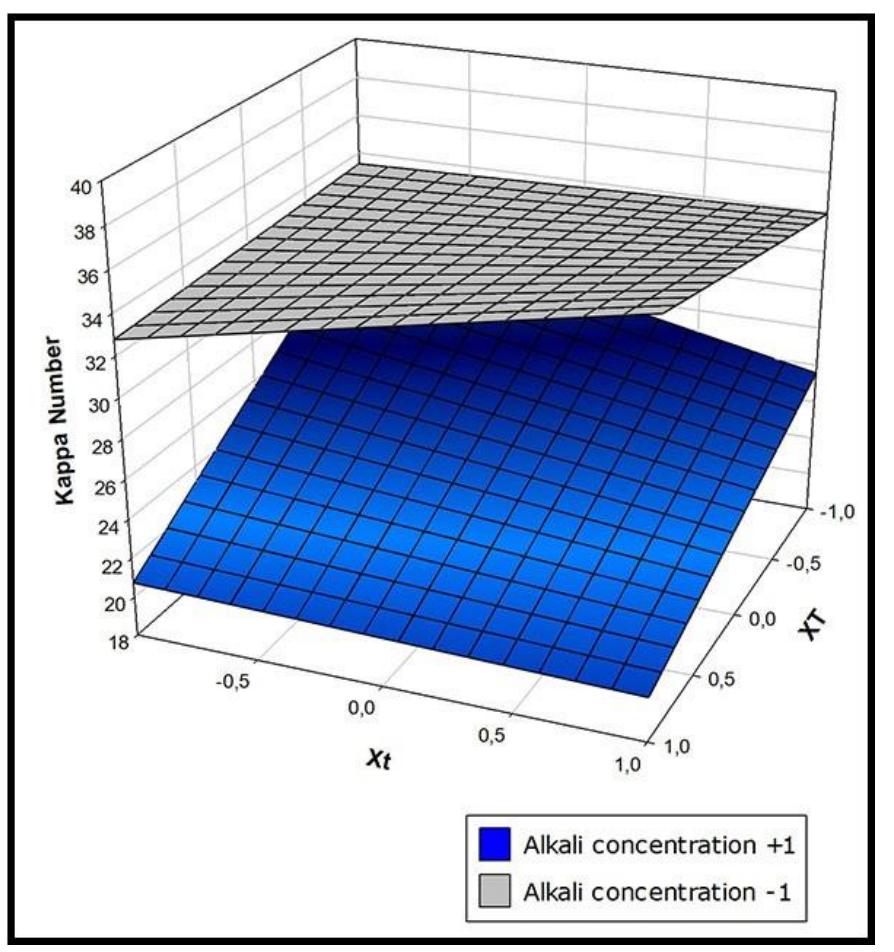

Fig. 3. Variation of the Kappa number as a function of temperature $\left(X_{T}\right)$ and operation time $\left(X_{t}\right)$, at two alkali concentrations levels 
Overall, the results were much lower than those reported by Loaiza et al. (2016) for the autohydrolysis and subsequent soda pulping of eucalyptus wood (kappa number ranging from 39.1 to 87.9 ). These results were especially interesting because they suggest that autohydrolysis facilitates subsequent delignification of the raw material. As a consequence, the autohydrolysis treatment leads to lower (more favorable) kappa numbers with lower alkali doses and temperatures, as well as shorter operation times.

The pulp viscosity was most markedly dependent on the autohydrolysis temperature. As shown in Fig. 4, it decreased as the soda concentration decreased, but was barely influenced by the temperature or treatment time, i.e., it was temperature- and timeindependent at low soda doses. However, using a high soda dose resulted in minor increases of viscosity.

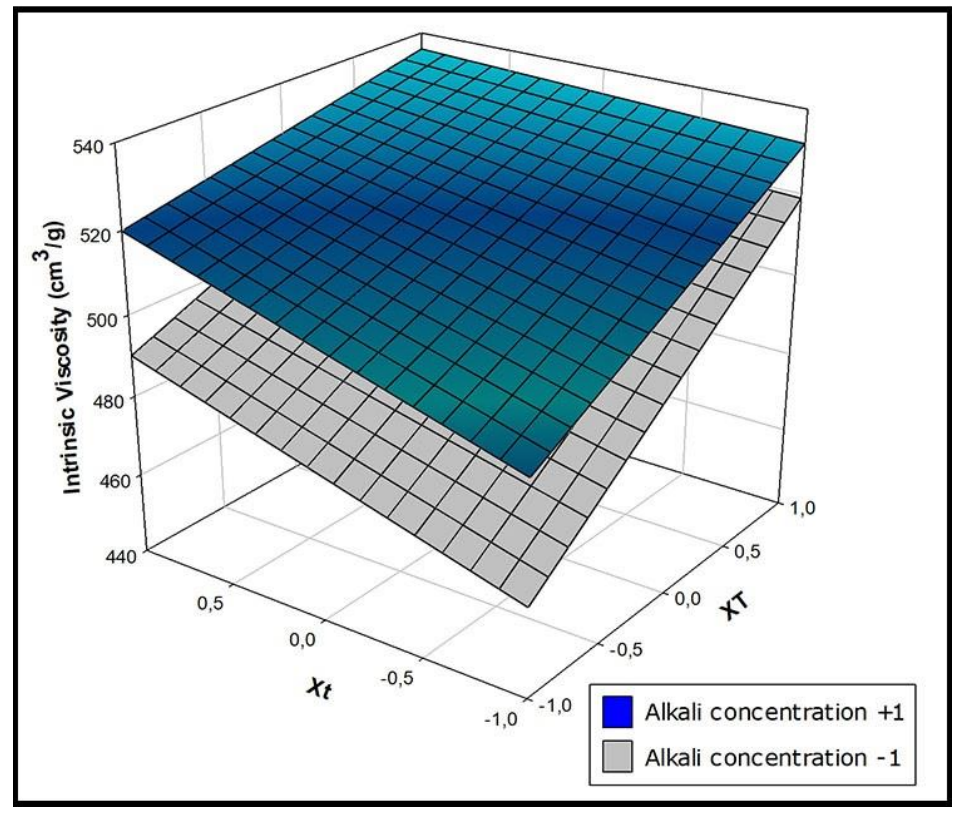

Fig. 4. Variation of the intrinsic viscosity as a function of temperature $\left(X_{T}\right)$ and operation time $\left(X_{t}\right)$, at two alkali concentrations levels

The response surfaces for the pulp samples obtained from the autohydrolysis solid phase are not shown. Instead, Table 4 shows the equations for the glucan, xylan, extractives, and Klason lignin contents. The xylan content of the pulp obtained from the solid was lower than that of the raw material because most of the hemicellulosic derivatives were removed by the autohydrolysis treatment. However, the hemicellulosic derivatives were not completely removed, which resulted in an improved tensile index in the paper sheets.

Figure 5 shows the variation of the tensile index with the alkali concentration and temperature at two different pulping times (normalized values of +1 and -1 ). As can be seen, the tensile index was as high as $22 \mathrm{~N} \cdot \mathrm{m} / \mathrm{g}$; hence, the tensile index was similar to the value obtained by Loaiza et al. (2016) using E. globulus, i.e., $22 \mathrm{~N} \cdot \mathrm{m} / \mathrm{g}$. These values, which were obtained with a soda concentration of approximately $20 \%$, and a medium treatment temperature and time, were consistent with the intrinsic viscosity data. As can be seen from Fig. 5, the viscosity peaked higher than $564 \mathrm{~cm}^{3} / \mathrm{g}$ at high active alkali concentrations and temperatures, and short treatment times. 


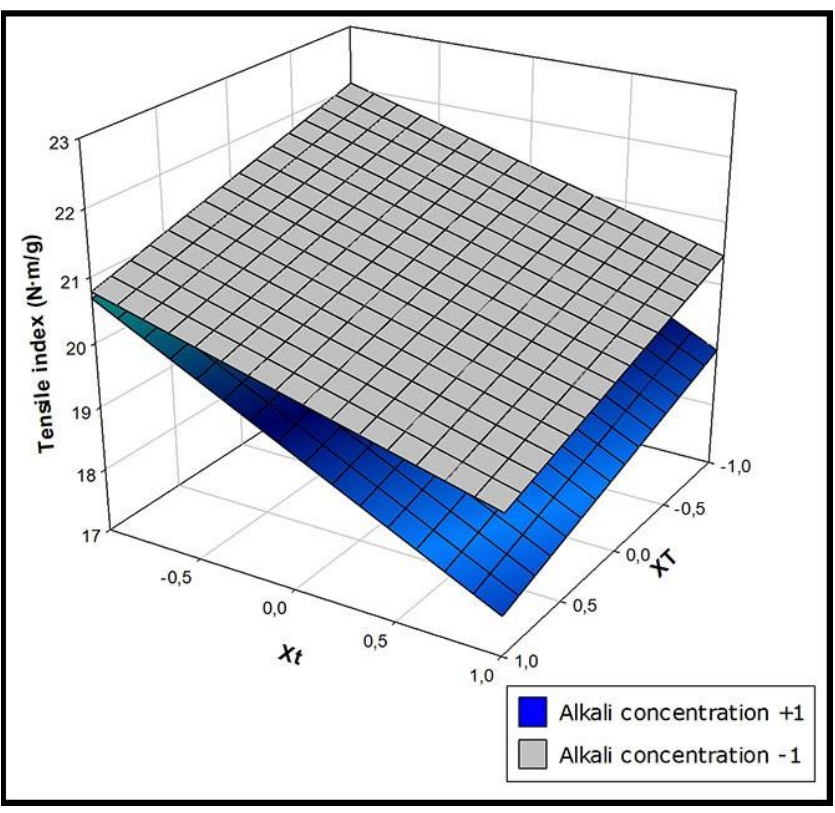

Fig. 5. Variation of the tensile index as a function of temperature $\left(X_{T}\right)$ and operation time $\left(X_{t}\right)$ at two alkali concentrations levels

Untreated samples of the raw material were also pulped for comparison with the autohydrolyzed material. Both were processed under the strongest conditions in order to confirm whether the pulp and paper properties were influenced by the extent of the hemicellulose extraction.

Table 5 shows such conditions in addition to the physical and chemical properties of the resulting pulp and paper. Although the differences between the pulp from the raw material and the solid phase from autohydrolysis were not significant and never exceeded $10 \%$, the autohydrolysis delignification treatment substantially improved the viscosity and kappa number in addition to providing a valorizable liquor containing $25 \%$ to $30 \%$ of the hemicellulose fraction found in the raw material. They are results consistent (or better) with those reported by Khider et al. (2012). Under similar operating conditions of temperature $\left(165\right.$ to $\left.170{ }^{\circ} \mathrm{C}\right)$, and higher operation time and alkali concentration $(210 \mathrm{~min}$ and $17 \%$ of active alkali as $\mathrm{Na}_{2} \mathrm{O}-21.93 \%$ as $\mathrm{NaOH}-$ ), pulp yield was between 40.8 and $41.2 \%$; kappa number was 22.7 and viscosity was between 746 and $836 \mathrm{ml} \mathrm{g}^{-1}$ (at $26^{\circ} \mathrm{SR}$ ).

Table 5. Comparison of the Pulp and Paper Properties Obtained With and Without Autohydrolysis of the Raw Material

\begin{tabular}{|c|c|c|c|c|c|c|}
\hline \multirow{2}{*}{ Properties } & \multicolumn{3}{|c|}{ Without Autohydrolysis } & \multicolumn{3}{c|}{ With Autohydrolysis } \\
\cline { 2 - 7 } & $\begin{array}{c}\text { Error } \\
+10 \%\end{array}$ & & $\begin{array}{c}\text { Error } \\
-10 \%\end{array}$ & $\begin{array}{c}\text { Error } \\
+10 \%\end{array}$ & $\begin{array}{c}\text { Error } \\
-10 \%\end{array}$ \\
\hline Yield (\%) & 39.0 & 35.5 & 31.9 & 40.4 & 36.4 & 32.7 \\
\hline $\begin{array}{c}\text { Tensile index } \\
(\mathrm{N} \cdot \mathrm{m} / \mathrm{g})\end{array}$ & 19.1 & 17.3 & 15.6 & 19.6 & 17.8 & 16.1 \\
\hline Glucan (\%) & 67.1 & 61.0 & 54.9 & 57.6 & 52.4 & 47.1 \\
\hline Xylan (\%) & 4.13 & 3.75 & 3.38 & 3.8 & 3.5 & 3.1 \\
\hline Viscosity (cm $3 / \mathrm{g})$ & 502.7 & 457.0 & 411.3 & 584.32 & 531.20 & 478.08 \\
\hline Klason lignin (\%) & 14.4 & 13.1 & 11.8 & 14.6 & 13.3 & 12.0 \\
\hline Kappa number & 27.4 & 24.9 & 22.4 & 23.0 & 20.9 & 18.8 \\
\hline Note: The $X_{C}, X_{T}$, and $X_{t}$ are $20 \%, 171^{\circ} \mathrm{C}$, and 120 min, respectively(for all samples) \\
\hline
\end{tabular}




\section{CONCLUSIONS}

1. Tule (Typha domingensis Pers) provided a suitable lignocellulosic biomass for biorefining via an autohydrolysis stage and an alkaline delignification stage. Alkaline cooking the solid residue obtained from the autohydrolysis process with a sodaanthraquinone mixture provided cellulose pulp and paper sheets with similar properties to paper sheets obtained from other raw materials in addition to a valorizable hemicellulose-containing liquor.

2. The physical properties of the paper sheets obtained from the autohydrolyzed material were acceptable, but somewhat poorer than those provided by other lignocellulosic biomasses, e.g., eucalyptus wood. In any case, these properties can be improved by the mechanical refining of the pulp.

3. Hydrothermal treatment of tule at temperatures below $141{ }^{\circ} \mathrm{C}$ led to an increased pulp yield and stronger paper sheets. The increased hemicellulose content of the raw material makes it especially suitable for the proposed use. In addition, the cellulose content is noticeably less degraded at the temperatures used in the hydrothermal treatment.

4. The autohydrolysis of tule before alkaline extraction makes it possible to obtain a valuable liquid phase that contains most of the hemicelluloses in the raw material. Also, the gross heating value for the hydrolyzed tule was increased with respect to the raw material.

5. In summary, tule lends itself readily to valorization for energy production, and also to integral, fractional exploitation via autohydrolysis and soda-anthraquinone delignification, which can additionally bring environmental benefits for sewage water treatment. The optimum autohydrolysis conditions for tule were a temperature of 141 ${ }^{\circ} \mathrm{C}$ and a pretreatment time of $45 \mathrm{~min}$. These conditions ensured a high cellulose (glucan) content in the solid phase and the presence of valorizable hemicellulosic derivatives in the liquor.

\section{ACKNOWLEDGMENTS}

This research work was funded by Spain's Ministry of Economy and Competitiveness (National Programme for Research Aimed at the Challenges of Society (No. CTQ2017-85251-C2-1-R) and Andalusian Regional Government (Project No. RNM 2323-2012) and a post-doctoral fellowship), as well as by the Technological Institute of

Ciudad Madero (Tamaulipas State), Mexico, and the National Technological of México (TecNM) with the project [rhh30r (8630)].

\section{REFERENCES CITED}

Alfaro, A., López, F., Pérez, A., García, J. C., and Rodríguez, A. (2010). “Integral valorization of tagasaste (Chamaecytisus proliferus) under hydrothermal and pulp processing," Bioresource Technology 101(19), 7635-7640. DOI:

10.1016/j.biortech.2010.04.059 
Alfaro, A., Rivera, A., Perez, A., Yañez, R., Garcia, J. C., and Lopez, F. (2009). "Integral valorization of two legumes by autohydrolysis and organosolv delignification," Bioresource Technology 100(1), 440-445. DOI: 10.1016/j.biortech.2008.05.003

Ang, S., Haritos, V., and Batchelor, W. (2020). "Cellulose nanofibers from recycled and virgin wood pulp: A comparative study of fiber development," Carbohydrate

Polymers 234, 115900. DOI: 10.1016/j.carbpol.2020.115900

Bajpai, P. (2016). "Chapter 2 - Global pulp and paper production and consumption," in: Pulp and Paper Industry: Energy Conservation, P. Bajpai (ed.), Elsevier, Amsterdam, Netherlands, pp. 9-14. https://doi.org/https://doi.org/10.1016/B978-0-12-8034118.00002-0

Bian, H., Gao, Y., Luo, J., Jiao, L., Wu, W., Fang, G., and Dai, H. (2019). "Lignocellulosic nanofibrils produced using wheat straw and their pulping solid residue: From agricultural waste to cellulose nanomaterials," Waste Management 91, 1-8. DOI: 10.1016/j.wasman.2019.04.052

Caparrós, S., Ariza, J., López, F., and Blanco, M. J. D. (2007). "Optimizing cellulosic paper obtained from Arundo donax L. under hydrothermal treatment," Journal of Industrial and Engineering Chemistry 13(3), 465-473.

Caparrós, S., Ariza, J., López, F., Nacimiento, J. A., Garrote, G., and Jiménez, L. (2008a). "Hydrothermal treatment and ethanol pulping of sunflower stalks," Bioresource Technology 99(5), 1368-1372. DOI: 10.1016/j.biortech.2007.01.045

Caparrós, S., Díaz, M. J., Ariza, J., López, F., and Jiménez, L. (2008b). “New perspectives for Paulownia fortunei L. valorisation of the autohydrolysis and pulping processes," Bioresource Technology 99(4), 741-749. DOI:

10.1016/j.biortech.2007.01.028

Cara, C., Ruiz, E., Carvalheiro, F., Moura, P., Ballesteros, I., Castro, E., and Gírio, F. (2012). "Production, purification and characterisation of oligosaccharides from olive tree pruning autohydrolysis," Industrial Crops and Products 40, 225-231. DOI: 10.1016/j.indcrop.2012.03.017

Cebreiros, F., Guigou, M. D., and Cabrera, M. N. (2017). "Integrated forest biorefineries: Recovery of acetic acid as a by-product from eucalyptus wood hemicellulosic hydrolysates by solvent extraction," Industrial Crops and Products 109, 101-108. DOI: 10.1016/j.indcrop.2017.08.012

CEN/TS 14918:2005 (2005). "Solid biofuels - Method for the determination of calorific value," National Standards Authority of Ireland, Dublin, Ireland.

César, N. R., Pereira-da-Silva, M. A., Botaro, V. R., and de Menezes, A. J. (2015). "Cellulose nanocrystals from natural fiber of the macrophyte Typha domingensis: Extraction and characterization," Cellulose 22, 449-460. DOI: 10.1007/s10570-0140533-7

Chen, M., Zhang, X., Liu, C., Sun, R., and Lu, F. (2014). "Approach to renewable lignocellulosic biomass film directly from bagasse," ACS Sustainable Chemistry \& Engineering 2(5), 1164-1168. DOI: $10.1021 / \mathrm{sc} 400555 \mathrm{v}$

Cherubini, F. (2010). "The biorefinery concept: Using biomass instead of oil for producing energy and chemicals," Energy Conversion and Management 51(7), 1412 1421. DOI: 10.1016/j.enconman.2010.01.015

Clark, J. H., Deswarte, F. E. I., and Farmer, T. J. (2009). "The integration of green chemistry into future biorefineries," Biofuels, Bioproducts and Biorefining 3(1), 72 90. DOI: $10.1002 / \mathrm{bbb} .119$

Cypriano, D. Z., da Silva, L. L., and Tasic, L. (2018). "High value-added products from 
the orange juice industry waste," Waste Management 79, 71-78. DOI:

10.1016/j.wasman.2018.07.028

Daya, B. B., and Nourelfath, M. (2019). "Sustainability assessment of integrated forest biorefinery implemented in Canadian pulp and paper mills," International Journal of Production Economics 214, 248-265. DOI: 10.1016/j.ijpe.2018.06.014

Duarte, G. V., Ramarao, B. V., Amidon, T. E., and Ferreira, P. T. (2011). "Effect of hot water extraction on hardwood kraft pulp fibers (Acer saccharum, sugar maple)," Industrial \& Engineering Chemistry Research 50(17), 9949-9959. DOI: $10.1021 / \mathrm{ie} 200639 \mathrm{u}$

FAO (2018). "Global forest products facts and figures," (http://www.fao.org/forestry/statistics/80938/en/), Accessed 16 October 2020.

Feria, M. J., López, F., García, J. C., Pérez, A., Zamudio, M. A. M., and Alfaro, A. (2011). "Valorization of Leucaena leucocephala for energy and chemicals from autohydrolysis," Biomass and Bioenergy 35(5), 2224-2233. DOI: 10.1016/j.biombioe.2011.02.038

Feria, M. J., Alfaro, A., López, F., Pérez, A., García, J. C., and Rivera, A. (2012). "Integral valorization of Leucaena diversifolia by hydrothermal and pulp processing," Bioresource Technology 103(1), 381-388. DOI: 10.1016/j.biortech.2011.09.100

Fišerová, M., and Opálená, E. (2012). "Hemicelluloses extraction from beech wood with water and alkaline solutions," Wood Research 57(4), 505-514.

García, J. C., Zamudio, M. A. M., Pérez, A., Feria, M. J., Gomide, J. L., Colodette, J. L., and López, F. (2011). "Soda-AQ pulping of Paulowina wood after hydrolysis treatment," BioResources 6(2), 971-986. DOI: 10.15376/biores.6.2.971-986

García-Domínguez, M. T., García-Domínguez, J. C., Feria, M. J., Gómez-Lozano, D. M., López, F., and Díaz, M. J. (2013). "Furfural production from Eucalyptus globulus: Optimizing by using neural fuzzy models," Chemical Engineering Journal 221, 185192. DOI: 10.1016/j.cej.2013.01.099

García, M. T., Alfaro, A., Garcia, J. C., Zamudio, M. A. M., Morales, A. B., and López, F. (2017). "Obtainment of hemicellulose derivatives and cellulose pulp from wheat straw following cold alkaline extraction," Cellulose Chemical Technology 51(5-6), 465-475.

Hamzeh, Y., Ashori, A., Khorasani, Z., Abdulkhani, A., and Abyaz, A. (2013). "Preextraction of hemicelluloses from bagasse fibers: Effects of dry-strength additives on paper properties," Industrial Crops and Products 43, 365-371. DOI:

10.1016/j.indcrop.2012.07.047

Khiari, R., Mhenni, M. F., Belgacem, M. N., and Mauret, E. (2010). “Chemical composition and pulping of date palm rachis and Posidonia oceanica - A comparison with other wood and non-wood fibre sources," Bioresource Technology 101(2), 775780. DOI: 10.1016/j.biortech.2009.08.079

Khider, T. O., Omer, S., and Taha, O. (2012). "Alkaline pulping of Typha domingensis stems from Sudan," World Applied Sciences Journal 16(3), 331-336.

Krishnan, K, A., Jose, C., R., R. K., and George, K. E. (2015). "Sisal nanofibril reinforced polypropylene/polystyrene blends: Morphology, mechanical, dynamic mechanical and water transmission studies," Industrial Crops and Products 71, 173184. DOI: 10.1016/j.indcrop.2015.03.076

Loaiza, J. M., López, F., García, M. T., Fernández, O., Díaz, M. J., and García, J. C. (2016). "Selecting the pre-hydrolysis conditions for eucalyptus wood in a fractional exploitation biorefining scheme," Journal of Wood Chemistry and Technology 36(3), 
211-223. DOI: $10.1080 / 02773813.2015 .1112402$

Loaiza, J. M., Alfaro, A., López, F., García, M. T., and García, J. C. (2019).

"Optimization of laccase/mediator system (LMS) stage applied in fractionation of

Eucalyptus globulus,” Polymers 11(4), 1-13. DOI: 10.3390/polym11040731

López, F., Feria, M. J., García, J. C., Zamudio, M. A. M., Pérez, A., and Rivera, A.

(2011). "Energy and autohydrolysis by-products from industrial crops," Journal of

Energy and Power Engineering 5(2), 142-148. DOI: 10.17265/1934-

8975/2011.02.007

López, F., Garcia, M. T., Mena, V., Loaiza, J. M., Zamudio, M. A. M., and Garcia, J. C. (2015). "Can acceptable pulp be obtained from Eucalyptus globulus wood chips after hemicellulose extraction?," BioResources 10(1), 55-67. DOI:

10.15376/biores.10.1.55-67

López, N. G., Moure, A., Domínguez, H., and Parajó, J. C. (2012). "Valorization of chestnut husks by non-isothermal hydrolysis," Industrial Crops and Products 36(1), 172-176. DOI: 10.1016/j.indcrop.2011.09.002

Medina, J. C. (1959). Plantas Fibrosas da Flora Mundial, Seção de Plantas Fibrosas, Instituto Agronômico, São Paulo, Brazil.

Mongkhonsiri, G., Gani, R., Malakul, P., and Assabumrungrat, S. (2018). "Integration of the biorefinery concept for development of sustainable processes for the pulp and paper industry," in: 13 th International Symposium on Process Systems Engineering, M. R. Eden, M. G. Ierapetritou, and G. P. Towler (eds.), Elsevier, Amsterdam, Netherlands, pp. 1135-1140.

Moniz, P., Pereira, H., Duarte, L.C., and Carvalheiro, F. (2014). "Hydrothermal production and gel filtration purification of xylo-oligosaccharides from rice straw," Industrial Crops and Products 62, 460-465. DOI: 10.1016/j.indcrop.2014.09.020

Morales-Cepeda, A. B., Ponce-Medina, M. E., Salas-Papayanopolos, H., Lozano, T., Zamudio, M., and Lafleur, P.G. (2015). "Preparation and characterization of candelilla fiber (Euphorbia antisyphilitica) and its reinforcing effect in polypropylene composites," Cellulose 22, 3839-3849. DOI: 10.1007/s10570-015-0776-y

Moriana, R., Vilaplana, F., and Ek, M. (2015). "Forest residues as renewable resources for bio-based polymeric materials and bioenergy: Chemical composition, structure and thermal properties," Cellulose 22, 3409-3423. DOI: 10.1007/s10570-015-0738-4

Mussatto, S. I., and Mancilha, I. M. (2007). "Non-digestible oligosaccharides: A review," Carbohydrate Polymers 68(3), 587-597. DOI: 10.1016/j.carbpol.2006.12.011

Nanda, S., Azargohar, R., Dalai, A. K., and Kozinski, J. A. (2015). "An assessment on the sustainability of lignocellulosic biomass for biorefining," Renewable and Sustainable Energy Reviews 50, 925-941. DOI: 10.1016/j.rser.2015.05.058

Pan, X., and Sano, Y. (2005). "Fractionation of wheat straw by atmospheric acetic acid process," Bioresource Technology 96(11), 1256-1263. DOI:

10.1016/j.biortech.2004.10.018

Pätäri, S., Tuppura, A., Toppinen, A., and Korhonen, J. (2016). “Global sustainability megaforces in shaping the future of the European pulp and paper industry towards a bioeconomy," Force Policy and Economics 66, 38-46. DOI:

10.1016/j.forpol.2015.10.009

Patel, S., and Goyal, A. (2011). "Functional oligosaccharides: Production, properties and applications," World Journal of Microbiology and Biotechnology 27, 1119-1128.

DOI: $10.1007 / \mathrm{s} 11274-010-0558-5$

Pio, D. T., Tarelho, L. A. C., and Pinto, P. C. R. (2020). “Gasification-based biorefinery 
integration in the pulp and paper industry: A critical review," Renewable and Sustainable Energy Reviews 133, 110210. DOI: 10.1016/j.rser.2020.110210

Rivas, B., Domínguez, J. M., Domínguez, H., and Parajó, J. (2002). “Bioconversion of posthydrolysed autohydrolysis liquors: An alternative for xylitol production from corn cobs," Enzyme and Microbial Technology 31(4), 431-438. DOI: 10.1016/S01410229(02)00098-4

Rogers, J. G., Cooper, S. J., and Norman, J. B. (2018). "Uses of industrial energy benchmarking with reference to the pulp and paper industries," Renewable and Sustainable Energy Reviews 95, 23-37. DOI: 10.1016/j.rser.2018.06.019

Saha, B. C. (2003). "Hemicellulose bioconversion," Journal of Industrial Microbiology and Biotechnology 30(5), 279-291. DOI: 10.1007/s10295-003-0049-x

TAPPI 211 om-02 (2002). "Ash in wood, pulp, paper and paperboard: Combustion at $525^{\circ} \mathrm{C}$," TAPPI Press, Atlanta, GA.

TAPPI T204 cm-07 (2007). "Solvent extractives of wood and pulp," TAPPI Press, Atlanta, GA.

TAPPI T205 sp-02 (2012). "Forming handsheets for physical test of pulp," TAPPI Press, Atlanta, GA.

TAPPI T220 sp-01 (2001). "Physical testing of pulp handsheets," TAPPI Press, Atlanta, GA.

TAPPI T222 om-11 (2011). “Acid-insoluble lignin in wood and pulp,” TAPPI Press, Atlanta, GA.

TAPPI T230 om-99 (1999). "Viscosity of pulp (capillary viscometer method)," TAPPI Press, Atlanta, GA.

TAPPI T236 cm-85 (1996). “Kappa number of pulp,” TAPPI Press, Atlanta, GA.

TAPPI T249 cm-09 (2009). "Carbohydrate composition of extractive-free wood and wood pulp by gas-liquid chromatography," TAPPI Press, Atlanta, GA.

TAPPI T257 cm-85 (1999). "Sampling and preparing wood for analysis," TAPPI Press, Atlanta, GA.

TAPPI T264 cm-07 (2007). "Preparation of wood for chemical analysis," TAPPI Press, Atlanta, GA.

TAPPI T494 om-01 (2001). "Tensile properties of paper and paperboard (using constant rate of elongation apparatus)," TAPPI Press, Atlanta, GA.

UNE 16001 EX. (2005). "Solid biofuels, method for the determination of calorific value," Spanish Association for Standardization, Madrid, Spain.

Vera, A., Andrade, C., Flores, E., Nañez, M., Cardenas, C., and Morales, E. (2010). "Removal of nutrients and organic matter in a constructed wetland, in function of the development of the macrophyte Typha dominguensis Pers.," Revista Técnica de la Facultad de Ingeniería Universidad del Zulia 33(2), 153-163.

Vila, C., Romero, J., Francisco, J. L., Garrote, G., and Parajó, J. C. (2011). "Extracting value from Eucalyptus wood before kraft pulping: Effects of hemicelluloses solubilization on pulp properties," Bioresource Technology 102(8), 5251-5254. DOI: 10.1016/j.biortech.2011.02.002

Wikberg, H., Grönqvist, S., Niemi, P., Mikkelson, A., Siika-aho, M., Kanerva, H., Käsper, A., and Tamminen, T. (2017). "Hydrothermal treatment followed by enzymatic hydrolysis and hydrothermal carbonization as means to valorise agro- and forest-based biomass residues," Bioresource Technology 235, 70-78. DOI: 10.1016/j.biortech.2017.03.095

Yedro, F. M., Cantero, D. A., Pascual, M., García-Serna, J., and Cocero, M.J. (2015). 
"Hydrothermal fractionation of woody biomass: Lignin effect on sugars recovery," Bioresource Technology 191, 124-132. DOI: 10.1016/j.biortech.2015.05.004

Yoo, C. G., Meng, X., Pu, Y., and Ragauskas, A. J. (2020). "The critical role of lignin in lignocellulosic biomass conversion and recent pretreatment strategies: A comprehensive review," Bioresource Technology 301, 122784. DOI: 10.1016/j.biortech.2020.122784

Zhu, J. Y., and Zhuang, X. S. (2012). "Conceptual net energy output for biofuel production from lignocellulosic biomass through biorefining," Progress in Energy and Combustion Science 38(4), 583-598. DOI: 10.1016/j.pecs.2012.03.007

Article submitted: January 19, 2021; Peer review completed: February 28, 2021; Revised version received and accepted: March 13, 2021; Published: March 19, 2021.

DOI: $10.15376 /$ biores.16.2.3328-3347 